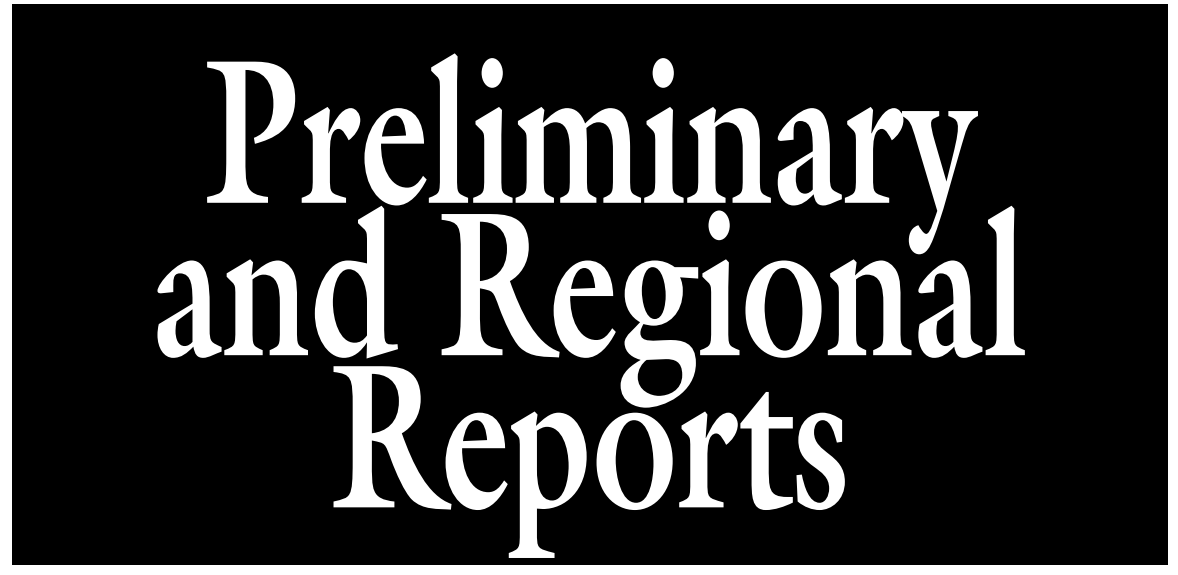

\section{Composting As an Alternative Management Strategy for Wild Taro Waste}

\author{
Jen A. Sembera ${ }^{1}$, Tina M. Waliczek ${ }^{2,3}$, and Erica J. Meier ${ }^{1}$
}

AdDitionAl INDEX wORDs. aquatic plant management, Colocasia esculenta, compost, compost quality, exotic, invasive species

Summary. Wild taro (Colocasia esculenta) is identified as an invasive species in freshwater regions throughout the southeastern United States as well as Puerto Rico, Jamaica, and India, and thrives in freshwater swamps, streambanks, and riparian areas with rocky crevices that provide strong footholds. Management methods for the plant include using herbicides, mechanical cutting, manual removal, or a combination of methods with disposal into landfills. The purpose of this study was to evaluate the potential to manage wild taro waste using composting and to test the quality of the resulting compost. This study used $\approx 12$ yard $^{3}$ of wild taro mixed with food waste and regionally harvested wood chips to create $\approx 6$ yard $^{3}$ of cured compost. Oven propagule mortality tests determined wild taro propagules exposed to temperatures between 45 and $52{ }^{\circ} \mathrm{C}$ for a minimum of 3 days were killed. These temperatures were achieved during the active phase of the composting process. The final compost products created were of equal or higher quality to current compost standards. Therefore, this study determined composting and waste management industries can accept and incorporate wild taro as a feedstock to create a desirable compost product for application in the horticulture and agriculture fields rather than managing the species with herbicides and/or other disposal methods.

$\mathrm{I}$ nvasive species pose a threat to plant and wildlife communities worldwide and are now considered to be a major detrimental factor of global change (Sakai et al., 2001).

Received for publication 20 Sept. 2018. Accepted for publication 15 Jan. 2019.

Published online 15 March 2019.

Department of Agriculture, Texas State University, 601 University Drive, San Marcos, TX 78666

${ }^{1}$ Graduate Student

${ }^{2}$ Professor of Horticulture

${ }^{3}$ Corresponding author. E-mail: tcl0@txstate.edu.

This is an open access article distributed under the CC BY-NC-ND license (https://creativecommons.org/ licenses/by-nc-nd $/ 4.0 /$ ).

https://doi.org/10.21273/HORTTECH04194-18
Exotic invasive aquatic species negatively impact local biodiversity, nutrients, light and oxygen availability, native shoreline vegetation, and human recreation and activity (Florida Exotic
Pest Plant Council, 2017; Reichard and White 2001). Invasive traits include the ability to reproduce asexually, competitive ability, rapid maturity rates, adaption to environmental stresses, and having an additional advantage of being connected to waterways allowing rapid spread after flooding events and/or human activity (Florida Exotic Pest Plant Council, 2013; Sakai et al., 2001). Public and private spending to prevent, control, or eliminate exotic invasive species was estimated to exceed $\$ 100$ million each year (Masser, 2007; Simberloff, 2003; U.S. Fish and Wildlife Service, 2012).

Indigenous to the New Guinea and Oceania regions, wild taro is an ancient crop used at the time of the earliest agricultural practices (Fullagar et al., 2005; Matthews, 2003). It was first introduced into Florida by the U.S. Department of Agriculture and other southern states as a potential substitute for potato (Solanum tuberosum) in 1910 (Atkins and Williamson, 2008; Langeland and Craddock Burks, 1998). From 1914 to 1924, the Texas Agricultural Experiment Station in Angleton experimented using taro as a potato replacement (Kimmel, 2006). The plant remains a commercially important food crop where the leaves, petioles, and roots are used and prepared in a variety of ways in cultures around the world. Taro is considered a dietary staple by some due to its high nutritional value (Manner and Taylor, 2011).

Ornamental cultivars of wild taro are also a valuable crop in the United States and around the world with species grown in Florida having, in part, an estimated overall horticultural economic value of $\$ 45$ million (Wirth et al., 2004). New ornamental cultivars and closely related species of plants have been developed, described, used, and bred for the floriculture and nursery trade (Cao and

\begin{tabular}{llll}
\hline $\begin{array}{l}\text { Units } \\
\begin{array}{l}\text { To convert U.S. to SI, } \\
\text { multiply by }\end{array}\end{array}$ & U.S. unit & SI unit & $\begin{array}{l}\text { To convert SI to U.S., } \\
\text { multiply by }\end{array}$ \\
\hline 0.4047 & $\mathrm{acre}(\mathrm{s})$ & $\mathrm{ha}$ & 2.4711 \\
29.5735 & $\mathrm{fl} \mathrm{oz}$ & $\mathrm{mL}$ & 0.0338 \\
0.3048 & $\mathrm{ft}$ & $\mathrm{m}$ & 3.2808 \\
3.7854 & $\mathrm{gal}$ & $\mathrm{L}$ & 0.2642 \\
2.54 & inch $(\mathrm{es})$ & $\mathrm{cm}$ & 0.3937 \\
1 & $\mathrm{mmho} / \mathrm{cm}$ & $\mathrm{dS} \cdot \mathrm{m}^{-1}$ & 1 \\
0.001 & $\mathrm{ppm}$ & $\mathrm{mg} \cdot \mathrm{g}^{-1}$ & 1000 \\
1 & $\mathrm{ppm}$ & $\mathrm{mg} \cdot \mathrm{kg}^{-1}$ & 1 \\
0.7646 & yard & $\mathrm{m}^{3}$ & 1.3080 \\
$\left({ }^{\circ} \mathrm{F}-32\right) \div 1.8$ & ${ }^{\circ} \mathrm{F}$ & ${ }^{\circ} \mathrm{C}$ & $\left({ }^{\circ} \mathrm{C} \times 1.8\right)+32$
\end{tabular}


Long, 2003; Pereira et al., 2005). Ornamental propagation of plants is often done using micropropagation (Adelberg and Toler, 2004). However, Manner and Taylor (2011) noted that wild taro was commercially produced in Hawaii "from mature (rhizomes) and consist(ed) of the top $1 \mathrm{~cm}$ of the rhizome and about 20 to $50 \mathrm{~cm}$ of the petiole."

In the southeastern United States, as well as in Puerto Rico, Jamaica, and India, wild taro is identified as an invasive exotic ornamental species in freshwater swamps, streambanks, and river bank areas (Atkins and Williamson, 2008; Bindu and Ramasamy, 2008; Early Detection and Distribution Mapping System, 2018; Everitt et al., 2007; Florida Exotic Pest Plant Council, 2017; Kurien and Ramasamy, 2006; Matthews, 2003). Extensive stands of wild taro live in a variety of riparian habitats and are superior competitors against native species (Atkins and Williamson, 2008; Gonzalez and Christoffersen, 2006). Plants prevent light from reaching submerged species below the leaf cover, increase the rates of evapotranspiration, and offer little value to local wildlife (Atkins and Williamson, 2008; Everitt et al., 2007). The presence of crystalized calcium oxalate in the leaves, stems, and root structures allow for no natural predation in the United States, increasing its ability to outcompete native species (Atkins and Williamson, 2008). Wild taro is often dispersed by purposeful or accidental spread of vegetation fragments (Atkins and Williamson, 2008; Gonzalez and Christoffersen, 2006). Chemical treatments currently used to manage wild taro can damage local ecosystems and are potentially less effective when compared with alternative means of management (Atkins and Williamson, 2008; Nelson and Getsinger, 2000).

Atkins and Williamson (2008) assessed four techniques for removal of invasive stands of wild taro to determine which process reduced the most organism biomass and resulted in the highest level of vegetative growth prevention. Methods included the use of glyphosate herbicide, mechanical cutting, manual removal, and a combination of mechanical cutting and herbicide use. Manual removal consisted of "hand pulling the entire plant, including the (rhizome), from the soil" and was the most effective method for wild taro harvesting and growth prevention (Atkins and Williamson, 2008). Proper disposal of harvested invasive plant parts is an important consideration because many invasive plants reproduce easily and successfully both sexually and asexually where any plant propagule could potentially produce new stands of plants (Florida Exotic Pest Plant Council, 2013).

Composting is a biomechanical process during which microorganisms such as bacteria and fungi convert organic matter into a waste-free, soil-like product (Epstein, 1997; Rynk, 1992). The mechanical manipulation increases the rate of decomposition that occurs in natural environments (Pennsylvania State University, 2012) and the process can take as little as 2 weeks to more than 1 year to complete, depending on the amount of human intervention, types of feedstocks used, and weather conditions (Epstein, 1997; Rynk, 1992). In addition, if high enough temperatures of 49 to $82^{\circ} \mathrm{C}$ are reached during the active stage and sustained for a period ( 3 to $7 \mathrm{~d}$ ), various types of weed seeds and additional propagules are killed (Meier et al., 2014; Montoya et al., 2013). Composting is increasingly used as a waste management method, a technique for pollution diversion, and a means to produce a valuable commodity for agricultural, horticultural, and related users (Walker et al., 2006). Composting is sometimes recommended as a means of managing invasive plant species waste if temperatures achieved in the composting process are hot enough and maintained for long enough periods (Florida Exotic Pest Plant Council, 2013).

The purpose of this study was to evaluate the potential to manage wild taro waste using composting and to test the quality of the resulting compost.

\section{Materials and methods}

A case study approach was used for the study and is considered appropriate when collecting data in an applied setting in which little information is known regarding the topic at hand (Noor, 2008).

Material Collection. All stands of wild taro were obtained from the shoreline of Spring Lake, the headwaters of the San Marcos River,
San Marcos, TX, where the plants were originally planted for landscaping purposes and are now considered a threat to the habitat of several endangered species (Montoya et al., 2013). Plants were harvested via Atkins and Williamson's (2008) method for manual removal. Given that disturbance and accidental dispersal of vegetative fragments may result in proliferation of the species, care was taken to ensure all plant fragments were collected. The U.S. Fish and Wildlife Service oversaw measures used to protect federally endangered species known to be in the area and condoned the management practices used (A. Wallendorf, personal communication). A total of $\approx 15 \operatorname{yard}^{3}$ of entire wild taro plants, including underground root-like structures, stems, and leaves, were collected. Similar biomass amounts were harvested in related studies studying composting as a management system for invasive species waste (Meier et al., 2014; Montoya et al., 2013).

OVEN PROPAGULE MORTALITY TESTS. Oven mortality tests were used to mimic conditions in active composting piles and identified the average temperature at which wild taro propagules were killed. The oven mortality tests used six ovens (model 10AF; Quincy Laboratory, Chicago, IL). Each oven was turned on $24 \mathrm{~h}$ in advance so that the desired temperature could be achieved and sustained before the propagules were added to the 6-inch-wide terra cotta containers filled with manufactured compost. Propagules and distilled water were added to the compost samples the day of the test to compensate for water loss during initial heating.

A total of 270 harvested and randomly selected propagules of different sizes were included in the oven mortality tests. Thirty propagules of wild taro were planted in compost and containers at oven temperatures of 45 to 52,53 to 61 , and 62 to $71^{\circ} \mathrm{C}$ for $3 \mathrm{~d}$, replicating similar studies (Meier et al., 2014), and tests were repeated three times. Similar temperatures are achieved in large-scale composting system piles and the 3$\mathrm{d}$ period mimics the minimum time materials would be held in the interior or core of the compost piles before turning or mixing of the piles would occur and the time needed at those temperatures in past studies to kill weed seeds and pathogens (Meier 
et al., 2014; Montoya et al., 2013). Oven temperature, substrate temperature, container moisture level, and humidity level were checked each day and adjusted if necessary (GeneralPurpose Mercury Laboratory Thermometer; Fisher Scientific, Pittsburgh, PA). Distilled water was used to maintain a moisture level in the substrate of $50 \%$ to $70 \%$ and the viability of the compost (Rynk, 1992). At the end of $3 \mathrm{~d}$, propagules were screened from the compost. If a propagule showed any sign of viability (e.g., turgidity, lack of odor, root growth, or green color), the sample underwent growth tests for a 14 -d period in greenhouses with optimal growth conditions to determine viability.

COMPOST PILE CREATION AND MANAGEMENT. Four piles $\approx 6 \mathrm{ft}$ in height and $10 \mathrm{ft}$ in length were created. Each pile contained 3 yard $^{3}$ (25\%) wild taro, $3 \operatorname{yard}^{3}$ (25\%) food waste from university cafeterias, and 6 yard $^{3}(50 \%)$ wood chips produced and donated by a local tree care company. Compost piles were created on a 5 -acre plot of land where $\approx 2.5$ acres are allocated for the compost site and the other 2.5 acres surrounding the compost site served as runoff space and a catchment pond that could withstand a 25-year 24-h flooding event (Meier et al., 2014).

Every 5-7 d, piles were turned regularly and monitored given compost industry standards (Dougherty, 1999). Readings were taken from five areas within each pile and averaged to ensure the following ideals were reached: $\mathrm{pH}$ between 5.5 and 9.0 (Soil $\mathrm{pH}$ direct reading sensor; Kelway, Wyckoff, NJ), moisture content between $40 \%$ and $65 \%$, and temperatures meeting the minimum requirements given the results of the oven mortality tests (Super Duty - Fast Response Windrow Compost Thermometer; Reotemp Instrument Corp., San Diego, $\mathrm{CA})$. After the active composting phase, piles were allowed to cure for at least 4 weeks to complete the composting process (Dougherty, 1999; Rynk, 1992).

Compost QUALITY TESTS. After curing, samples were drawn from the compost. Sampling techniques adhered to the collection procedures specified by the Agricultural Analytical Services Laboratory at Pennsylvania State University (2012). For each test, subsamples from each compost pile were collected from three different depths at five locations. These 15 subsamples were combined to create two 0.5-gal composite samples representative of the compost piles from which they were drawn, which were then sent to the Agricultural Analytical Services Laboratory's U.S. Composting Council's Seal of Testing Approval (STA) program at Pennsylvania State University (University Park). The samples were evaluated on the following characteristics: $\mathrm{pH}$, soluble salt content or EC, moisture content, organic matter content, total nitrogen, total carbon, carbonto-nitrogen ratio, phosphorus, potassium, calcium, magnesium, particle size, and metals arsenic, cadmium, copper, lead, mercury, molybdenum, nickel, selenium, and zinc. Respirometry and bioassay tests were also conducted to observe maturity and stability measurements of compost samples (Meier et al., 2014; Montoya et al., 2013; Pennsylvania State University, 2012; U.S. Composting Council, 2002).

INDEPENDENT RESEARCH TESTS. Each composite sample was manually screened through a 0.5 -inch screener to identify remaining propagules. Wild taro propagules that had not decomposed during composting were subjected to growth tests in a greenhouse environment in optimal growth conditions.

Data analysis. Frequencies and descriptive data were reported at each stage of the project. Previous related studies did not require more extensive data analyses because propagules were identified as either being present or not-present and compost samples were identified as either having highquality product characteristics or not meeting quality requirements (Meier et al., 2014; Montoya et al., 2013).

\section{Results and discussion}

Wild TARo OVEn MORTALITy. Observation of the viability tests completed on the 270 wild taro samples showed that propagules decomposed during the oven mortality tests or the subsequent post-oven mortality growth tests. All propagules lost turgidity, became dark brown in color, were malodorous, and failed to show signs of growth via root formation when exposed to temperatures of 45 to $52{ }^{\circ} \mathrm{C}$ for a minimum of $3 \mathrm{~d}$. Therefore, it was determined that wild taro propagules must be exposed to these temperatures when incorporated into composting piles to be killed. Similar results regarding mortality of plant propagules have been identified in related studies with other species, including water hyacinth (Eichhornia crassipes), water lettuce (Pistia stratiotes), and hydrilla (Hydrilla verticillata) (Meier et al., 2014; Montoya et al., 2013).

Compost MANAgEMENT AND QUALITY TESTS RESULTS. Following the reduction of materials during the composting process, $\approx 6$ yard $^{3}$ of cured compost were created. A total of $\approx 25 \mathrm{~mL}$ of wild taro remains were identified by the researcher in the 45 gal composite sample from piles using turgid wild taro propagules as a feedstock. None were identified as viable due to their brown or black color and/or lack of turgidity. Individual wild taro remains in the material screened out of the compost piles included rhizomes from $\approx 0.5$ to 1.5 inches in length and were also dead given inspection. In a typical large-scale composting system, remaining propagule fragments could be screened out with additional large carbon-based fragments (e.g., nondecomposed wood chips) and then reincorporated into future composting cycles. Because of the small size and fine consistency of the remaining biomass, the propagules were expected to decompose after one additional compost cycle.

Results based on the U.S. Composting Council's Tests Methods for the Examination of Composting and Compost (2002) used by the STA program were positive. The $\mathrm{pH}$, soluble salt content, total nitrogen, total carbon, carbon-to-nitrogen ratio, particle size, bioassay, and respirometry measurements of all samples were within the ideal and desirable ranges for compost sold in the horticultural industry (Table 1 ). In addition, heavy metal content did not exceed normal ranges nor were weed seeds or other viable plant species propagules present.

According to the U.S. Composting Council (2002), the ideal $\mathrm{pH}$ range for compost is between 5.0 and 8.5. The measurements of the wild taro compost samples ranged from 8.3 to 8.4. Although these measurements were alkaline, they were within the acceptable $\mathrm{pH}$ ranges for finished compost (U.S. Composting Council, 2002) (Table 1). 
Table 1. Compost quality test results of compost created from wild taro in the study of composting as an alternative management strategy for wild taro waste.

\begin{tabular}{|c|c|c|c|c|c|}
\hline Variable (units) $^{\mathrm{z}}$ & $\begin{array}{c}\text { Range } \\
\text { (as is basis) }\end{array}$ & $\begin{array}{c}\text { Mean } \\
\text { (as is basis) }\end{array}$ & $\begin{array}{c}\text { Range } \\
\text { (dry wt basis) }\end{array}$ & $\begin{array}{c}\text { Mean } \\
\text { (dry wt basis) }\end{array}$ & $\begin{array}{l}\text { Normal range } \\
\text { (USCC) }^{\mathrm{y}}\end{array}$ \\
\hline $\mathrm{pH}$ & $8.3-8.4$ & 8.35 & - & - & $5.0-8.5$ \\
\hline Soluble salts $(\mathrm{mmho} / \mathrm{cm})^{\mathrm{y}}$ & $1.1-1.5$ & 1.3 & - & - & $1-10$ \\
\hline Solids (\%) & $57.0-63.9$ & 60.45 & - & - & $50-60$ \\
\hline Moisture (\%) & $36.1-43.0$ & 39.55 & - & - & $40-50$ \\
\hline Organic matter $(\%)$ & $17.8-22.2$ & 20.0 & $31.2-34.7$ & 32.95 & 30-70 (dry wt) \\
\hline Carbon-to-nitrogen (ratio) & $12.4-13.4$ & 12.9 & $12.4-13.4$ & 12.9 & $<20($ dry wt $)$ \\
\hline Phosphorus (\%) & $0.31-0.43$ & 0.37 & $0.55-0.68$ & 0.62 & - \\
\hline Potassium (\%) & $0.39-0.46$ & 0.43 & $0.68-0.72$ & 0.70 & - \\
\hline Magnesium (\%) & $0.24-0.25$ & 0.24 & $0.39-0.42$ & 0.41 & - \\
\hline Arsenic $\left(\mathrm{mg} \cdot \mathrm{kg}^{-1}\right)$ & $4.2-4.9$ & 4.6 & $7.4-7.6$ & 7.5 & $<75$ \\
\hline Cadmium $\left(\mathrm{mg} \cdot \mathrm{kg}^{-1}\right)$ & $<0.3-<0.4$ & $<0.4$ & $<0.6$ & $<0.6$ & $<85$ \\
\hline Molybdenum $\left(\mathrm{mg} \cdot \mathrm{kg}^{-1}\right)$ & $<0.9-<1.1$ & 1.0 & $<1.7-<1.8$ & 1.8 & $<57$ \\
\hline Nickel $\left(\mathrm{mg} \cdot \mathrm{kg}^{-1}\right)$ & $5.4-5.6$ & 5.5 & $8.8-9.6$ & 9.2 & $<75$ \\
\hline Selenium $\left(\mathrm{mg} \cdot \mathrm{kg}^{-1}\right)$ & $<0.9-<1.1$ & 1.0 & $<1.7-<1.8$ & 1.8 & $<100$ \\
\hline Zinc $\left(\mathrm{mg} \cdot \mathrm{kg}^{-1}\right)$ & $37.7-45.1$ & 41.4 & $66.1-70.6$ & 68.4 & $<7500$ \\
\hline Bioassay: emergence (\% of control) & 100 & 100 & - & - & $>90$ (very mature) \\
\hline Bioassay: seedling vigor $(\%)$ & 100 & 100 & - & - & $>95$ (very mature) \\
\hline $\begin{array}{l}\text { Respirometry (mg carbon dioxide/ } \\
\text { g organic matter } / \mathrm{d} \text { ) }\end{array}$ & $1.8-2.0$ & 1.9 & - & - & $\begin{array}{c}<2 \text { (very stable) } \\
2-8(\text { stable }) \\
\end{array}$ \\
\hline
\end{tabular}

${ }^{\mathrm{z}} 1 \mathrm{mmho} / \mathrm{cm}=1 \mathrm{dS} \cdot \mathrm{m}^{-1}, 1 \mathrm{mg} \cdot \mathrm{kg}^{-1}=1 \mathrm{ppm}, 1 \mathrm{mg} \cdot \mathrm{g}^{-1}=1000 \mathrm{ppm}$.

${ }^{\mathrm{y}}$ U.S. Composting Council (2002).

Compost products created with initial ratios using more quantities of acidic feedstocks (e.g., food waste, leaf matter, or pine needles) would potentially result in products with more neutralized pH measurements (Cooperband, 2002; Dougherty, 1999). However, piles that are allowed to cure for 90 to $120 \mathrm{~d}$ tend to have lower $\mathrm{pH}$ measurements (Dougherty, 1999). Therefore, curing piles for longer than 30 $\mathrm{d}$ would allow the compost time to become more acidic if considered necessary.

Percent solids in the samples was normal to a little high $(57.0 \%$ to $63.9 \%$ ), whereas percent moisture was somewhat low [36.1\% to $43.0 \%$ (Table 1)]. The ideal percent solids amount was $50 \%$ to $60 \%$, whereas the ideal percent moisture content was $40 \%$ to $50 \%$ (U.S. Composting Council, 2002). The remains of the tunic, the dried membranous covering, from the rhizomes may have increased percent solids in samples. In the future, these could be screened more diligently to meet ideal levels of percent solids. Furthermore, samples lose moisture during the process of mailing to the testing laboratories, but in future efforts of working with this plant, compost could be moistened. Soluble salt content in each of the piles ranged from 1.10 to 1.50 $\mathrm{mmho} / \mathrm{cm}$ and was well within the safe soluble salt content range of 1.0 to $10.0 \mathrm{mmho} / \mathrm{cm}$ (U.S. Composting Council, 2002) (Table 1). The normal range of total nitrogen content identified by the U.S. Composting Council (2002) was between $0.5 \%$ and $2.5 \%$ (dry weight basis) The total nitrogen content in the representative samples ranged from $1.3 \%$ to $1.7 \%$. The ideal total carbon identified by the U.S. Composting Council (2002) was less than 54\%. The range of total carbon in the samples varied from $17.3 \%$ to $21.3 \%$. Carbonto-nitrogen ratios of 20 or below allow organic nitrogen to break down to an inorganic, plant-available form of nitrogen (U.S. Composting Council, 2002). The carbon-to-nitrogen ratios of the samples were between 12.40 and 13.40. Therefore, the compost produced in this study would increase plant nutrient availability when applied to soil.

Bioassay tests measured maturity of the compost based on emergence and seedling vigor. Compost is rated as "very mature" if emergence readings are greater than $90 \%$ and seedling vigor readings are greater than $95 \%$ (U.S. Composting Council, 2002). Measurements of all compost samples were identified at $100 \%$. Respirometry tests were conducted to determine the stability or microbial activity in the finished compost. The U.S. Composting Council (2002) rates compost with respirometry readings of 0.1 to 2.0 as "very stable," whereas readings from 2.1 to 8.0 are identified as "stable." The average respirometry reading for the compost samples was 1.9. Individual samples were identified within the range of 1.8 to 2.0 .

Trends shown here are considered preliminary given the case study approach. Results from this study are valuable, as few studies have focused on the potential of wild taro as a bioresource. Quality tests conducted on the representative samples identified the final compost products to have quality levels considered safe and desirable by the composting and horticultural industries. The lack of propagules present in the compost samples confirmed findings from laboratory tests showing 
that large-scale composting can be used to safely manage wild taro and be used to create a quality horticultural product. Therefore, if temperatures in compost piles reach 45 to $62^{\circ} \mathrm{C}$ for a minimum of $3 \mathrm{~d}$, then wild taro propagules can safely be composted, be an effective tool in the management of this invasive plant waste, and used as an alternative to the use of herbicides or disposal of the biomass in a landfill. This is an important finding regionally, as researchers have argued (Owens et al., 2001) that nearly $80 \%$ of the native shoreline aquatic plants along the San Marcos River had been replaced by exotic species including wild taro.

Furthermore, studies suggest that wild taro threatens habitats occupied by native vegetation similarly worldwide (Akridge and Fonteyn, 1981; Atkins and Williamson, 2008). This study found that composting offered an environmentally friendly, effective, and potentially profitable means of disposal for wild taro. Future studies should include a cost-benefit analysis of the environmental and monetary impacts of the removal of other invasive plant species by manual removal/composting as opposed to the use of chemical control (e.g., herbicides).

\section{Literature cited}

Adelberg, J. and J. Toler. 2004. Comparison of agar and an agitated think-film, liquid system for micropropagation of ornamental elephant ears. HortScience 39:1088-1092.

Akridge, R. and P.J. Fonteyn. 1981. Naturalization of Colocasia esculenta (Araceae) in the San Marcos River, Texas. Southwest. Nat. 26:210-211.

Atkins, E.O. and P.S. Williamson. 2008. Comparison of four techniques to control elephant ear. J. Aquat. Plant Mgt. 46: 158-162.

Bindu, T. and E.V. Ramasamy. 2008. Recovery of energy from taro (Colocasia esculenta) with solid-feed anaerobic digestors (SOFADs). Waste Mgt. 28:396-405.

Cao, L. and C. Long. 2003. Colocasia bicolor (Araceae), a new species from Yunnan China. Ann. Bot. Fenn. 40:283-286.

Cooperband, L. 2002. The art and science of composting: A resource for farmers and compost producers. 7 July 2017. $<$ http://www.cias.wisc.edu/wp-content/ uploads/ 2008/07/artofcompost.pdf>.

Dougherty, M. 1999. Field guide to onfarm composting. Natural Resources Coop. Ext. Agr. Eng. Serv. NRAES114.
Early Detection and Distribution Mapping System. 2018. Invasive plant atlas of the United States. 22 Dec. 2018. <https://www.invasiveplantatlas.org/ subject.html?sub $=5369>$.

Epstein, E. 1997. The science of composting. Routledge, New York, NY.

Everitt, J.H., C. Yang, and M.R. Davis. 2007. Mapping wild taro with color-infrared aerial photography and image processing. J. Aquat. Plant Mgt. 45:106-110.

Florida Exotic Pest Plant Council. 2013. Guidelines for disposal of terrestrial invasive plants. 8 Jan. 2019. <https://bugwoodcloud. org/CDN/fleppc/publications/ Florida_InvasivePIDisposalGuidelines. pdf>.

Florida Exotic Pest Plant Council. 2017. List of invasive plant species. 22 Dec. 2018. $<$ http://www.fleppc.org/ list/07list_ctrfld. pdfs.

Fullagar, R., J. Field, T. Denham, and C. Lentfer. 2005. Early and mid Holocene tool use and processing of taro (Colocasia esculenta), yam (Dioscorea sp.) and other plants at Kuk Swamp in the highlands of Papua New Guinea. J. Archaeol. Sci. 33:595-614.

Gonzalez, L. and B. Christoffersen. 2006. The quiet invasion: A guide to invasive plants of the Galveston Bay area. Texas Commission Environ. Quality, Austin, TX.

Kimmel, J. 2006. The San Marcos: A river's story. Texas A\&M Univ. Press, College Station, TX.

Kurien, J. and E.V. Ramasamy. 2006. Vermicomposting of taro (Colocasia esculenta) with two epigeic earthworm species. Bioresour. Technol. 97:1324-1328.

Langeland, K.A. and K. Craddock Burks. 1988. Identification and biology of nonnative plants in Florida's natural areas. Univ. Florida, Inst. Food Agr. Sci., Gainesville, FL.

Manner, H.I. and M. Taylor. 2011. Farm and forestry production and marketing profile for taro (Colocasia esculenta). 21 Dec. 2018. <http://pacificschoolserver. org/content/_public/Local\%20Topics/ Pacific\%20Islands/Agriculture\%20for\% 20Islands/Specialty\%20crops/Taro.pdfs.

Masser, M. 2007. Impacts of invasive aquatic plants. Southwest Hydrol. 6:22-33.

Matthews, P.J. 2003. Taro planthoppers (Tarophagus spp.) in Australia and the origins of taro (Colocasia esculenta) in Oceania. Archaeol. Ocean. 38:192-202.

Meier, E.J., T.M. Waliczek, and M. Abbott. 2014. Composting as a means of managing invasive plants in the Rio Grande River. Invasive Plant Sci. Mgt. 7:473-482.
Montoya, J., T.M. Waliczek, and M. Abbott. 2013. Large-scale composting as a means of managing water hyacinth, Eichhornia crassipes. Invasive Plant Sci. Mgt. 6:243-249.

Nelson, L.S. and K. Getsinger. 2000. Herbicide evaluation for control of wild taro. J. Aquat. Plant Manage. 38:70-72.

Noor, K. 2008. Case study: A strategic research methodology. Amer. J. Appl. Sci. 5:1602-1604.

Owens, C.S., J.D. Madsen, R.M. Smart, and R.M. Stewart. 2001. Dispersal of native and nonnative aquatic plant species in the San Marcos River, Texas. J. Aquat. Plant Mgt. 39:75-79.

Pereira, F.H.F., M. Puiatti, and F. Finger. 2005. Ornamental potential of taro [Colocasia esculenta (L.) Schott] accessions. Acta Hort. 683:307-312.

Pennsylvania State University. 2012. Compost analysis: Sampling and mailing procedure. Pennsylvania State Univ. Agr. Anal. Serv. Lab., University Park, PA.

Reichard, S.H. and P. White. 2001. Horticulture as a pathway of invasive plant introductions in the United States. Bioscience 51:103-113.

Rynk, R. (ed.). 1992. On-farm composting handbook. Natural Resources Agr. Eng. Serv. (NRAES) Coop. Ext., Ithaca, NY.

Sakai, A.K., F.W. Allendorf, J.S. Holt, D.M. Lodge, J. Molofsky, K.A. With, S. Baughman, R.J. Cabin, J.E. Cohen, N.C. Ellstrand, D.E. McCauley, P. O'Neil, I.M. Parker, J.N. Thompson, and S.G. Weller. 2001. The population biology of invasive species. Annu. Rev. Ecol. Syst. 32:305-332.

Simberloff, D. 2003. Eradication - Preventing invasions at the outset. Weed Sci. $51: 247-253$.

U.S. Composting Council. 2002. Test methods for the examination of composting and composts. (CDROM only). Composting Council Res. Educ. Foundation, Holbrook, NY.

U.S. Fish and Wildlife Service. 2012. The cost of invasive species. 13 Jan. 2019. <https://www.fws.gov/verobeach/ PythonPDF/CostofInvasivesFactSheet. pdf $>$.

Walker, P., D. Williams, and T.M. Waliczek. 2006. An analysis of the horticulture industry as a potential value-added market for composts. Compost Sci. Util. 14:23-31.

Wirth, F., K. Davis, and S. Wilson. 2004. Florida nursery sales and economic impacts of 14 potentially invasive landscape plant species. J. Environ. Hort. 22:12-16. 